\title{
Novel polycyclic Diels-Alder adducts from ring distorted 3-aza[5] and 3-aza[6] $(1,7)$ naphthalenophanes
}

\author{
John B Bremner ${ }^{a, *}$ and Wasna Jaturonrusmee ${ }^{b}$ \\ ${ }^{a}$ Department of Chemistry, University of Wollongong, Wollongong, NSW 2522 Australia, and \\ ${ }^{b}$ Department of Chemistry, Faculty of Science, King Monkut's Institute of Technology Thonburi, \\ Bangkok 10140, Thailand \\ E-mail: john_bremner@uow.edu.au
}

\section{Dedicated to Professor Jim Coxon on the occasion of his $65^{\text {th }}$ birthday.}

\begin{abstract}
Ring distorted 3-aza[5] and 3-aza[6](1,7)naphthalenophanes have been shown to undergo ready Diels-Alder cycloaddition reactions with 4-phenyl-1,2,4-triazoline-3,5-dione, tetracyanoethylene, 1,1-dicyanoethylene and 1,1-diethyl methylenemalonate to form new functionalized polycyclic heterocyclic derivatives. Addition was shown to occur selectively in each case in the less substituted aromatic ring of the naphthalene moiety.
\end{abstract}

Keywords: Diels-Alder adducts, aza-naphthalenophanes, ring distortion, polycyclic heterocycles

\section{Introduction}

While naphthalene and derivatives undergo Diels-Alder reactions, the number of such examples is relatively small and conditions are normally severe, or require Lewis acid activation of the dienophile $^{1}$, as a result of the energy penalty incurred on disrupting the aromaticity of the naphthalene system. $^{1-5}$ If the planarity of the naphthalene is partially disrupted by bulky substituents or by incorporating the naphthalene moiety in a short-bridged cyclophane, then the feasibility of this reaction is likely to be increased. ${ }^{6}$ Such a ring distortion occurs in the [5]- or [6]-aza-1,7-naphthalenophane systems. Diels-Alder reactions of these systems were of interest mechanistically to assess the effects of ring strain on reactivity. Also, synthetically, the cycloaddition afforded the possibility of facile access to compact and rigid polycyclic heterocyclic systems of potential interest as drug scaffolds. The results of some aspects of this work are now reported in this paper. 


\section{Results and Discussion}

The required 3-aza-[5] and [6]-(1,7)naphthalenophane precursors $(\mathbf{1} \mathbf{a}, \mathbf{b}, \mathbf{c})$ were prepared by application of the previously described ${ }^{7,8}$ ring destruction methodology to the appropriate fused isoquinoline derivatives and reaction with cyanogen bromide or methyl chloroformate. Reduction of the carbamate 1d with lithium aluminium hydride then afforded $^{8}$ the naphthalenophane (1c). Reaction of the potent dienophile 4-phenyl-1,2,4-triazoline-3,5-dione with (1a-c) took place very readily at room temperature to give the 1:1 adducts (2a), (2b) and (2c) respectively in good yield; no adducts could be isolated from attack on the dimethoxysubstituted ring (Scheme 1 and Table 1). The numbers on structure 2 refer to compounds with $n$ $=2$.<smiles>[R]N1CCCCCc2cc(OC)c(OC)c3ccc(cc23)CC1</smiles>

$(1 a, b, c, d)$

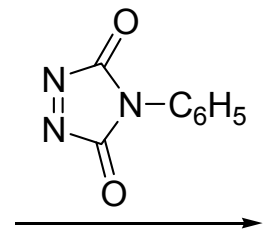

$\mathrm{H}_{3} \mathrm{CO}$

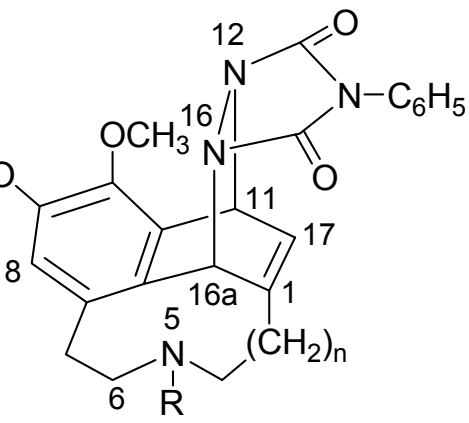

$(2 a, b, c)$

\begin{tabular}{cccc}
\hline $\mathbf{1}$ & $\mathbf{2}$ & $\mathrm{n}$ & $\mathrm{R}$ \\
\hline $\mathbf{a}$ & $\mathbf{a}$ & 1 & $\mathrm{CN}$ \\
$\mathbf{b}$ & $\mathbf{b}$ & 2 & $\mathrm{CN}$ \\
$\mathbf{c}$ & $\mathbf{c}$ & 2 & $\mathrm{CH}_{3}$ \\
$\mathbf{d}$ & - & 2 & $\mathrm{COOCH}_{3}$ \\
\hline
\end{tabular}

\section{Scheme 1}

Table 1. Diels-Alder reaction of the 3-aza(1,7)naphthalenophanes 1a-c with 4-phenyl-1,2,4triazoline-3,5-dione

\begin{tabular}{cccc}
\hline Compound & Reaction conditions & Adduct & Yield (\%) \\
\hline$(\mathbf{1 a})$ & $\mathrm{THF}, 20^{\circ} \mathrm{C}, 2 \mathrm{~h}$ & $\mathbf{( 2 a )}$ & 82 \\
$(\mathbf{1 b})$ & $\mathrm{THF}, 20^{\circ} \mathrm{C}, 4 \mathrm{~h}$ & $\mathbf{( 2 b )}$ & 78 \\
$(\mathbf{1 c})$ & $\mathrm{THF}, 20^{\circ} \mathrm{C}, 3.5 \mathrm{~h}$ & $\mathbf{( 2 c )}$ & 70 \\
\hline
\end{tabular}

In the case of the shorter bridged 3-aza[5](1,7)naphthalenophane (1a), the 1:1 adduct (2a) was obtained in $82 \%$ yield after a shorter period of time (completed reaction), indicating that (1a) is considerably more reactive than the larger bridged naphthalenophanes (1b) and (1c). This can be explained in terms of its higher strain ${ }^{7,9}$ in comparison to that of $(\mathbf{1 b})$ and (1c). 
The structural assignments of the adducts 2a-c were supported by analytical and spectroscopic data. Microanalysis of $2 \mathbf{a}$ indicated an empirical formula of $\mathrm{C}_{25} \mathrm{H}_{23} \mathrm{~N}_{5} \mathrm{O}_{4}$ and this was shown to be the molecular formula from high-resolution mass spectrometry. The infrared spectrum showed a strong absorption band at $2204 \mathrm{~cm}^{-1}$, consistent with the presence of cyanamide functionality ${ }^{10}$ and a sharp doublet at 1770 and $1712 \mathrm{~cm}^{-1}$, characteristic of the fivemembered cyclic imide component. ${ }^{11}$ The ${ }^{1} \mathrm{H}$ NMR spectrum of the adduct $\mathbf{2 a}$ showed broadened peaks at $25{ }^{\circ} \mathrm{C}$ due to conformational interconversion of the bridging aza-methylene ring. As the temperature was increased sharpened signals were observed. At $50{ }^{\circ} \mathrm{C}$ in the ${ }^{1} \mathrm{H}$ NMR spectrum of $2 \mathbf{a}$, a one-proton singlet at $\delta 6.44$ and another one-proton singlet at $\delta 6.08$ was ascribed to the aromatic proton $\mathrm{H}-7$ and the bridgehead proton $\mathrm{H}-15 \mathrm{a}$ respectively, while a one-proton doublet at $\delta 6.54(J=5.7 \mathrm{~Hz})$ was assigned to the olefinic proton $\mathrm{H}-16$. The other bridgehead proton $\mathrm{H}-10$ appeared as a doublet at $\delta 6.20(J=5.7 \mathrm{~Hz})$.

In the ${ }^{1} \mathrm{H}$ NMR spectrum of the adduct $\mathbf{2 b}$, a one-proton singlet at $\delta 6.51$ was attributed to the aromatic proton $\mathrm{H}-8$. A doublet of doublets centred at $\delta 6.55(J=5.9,1.6 \mathrm{~Hz})$ and two oneproton doublets at $\delta 6.01(J=1.6 \mathrm{~Hz})$ and at $\delta 6.23(J=5.9 \mathrm{~Hz})$ were assigned to the olefinic proton $\mathrm{H}-17$ and the bridgehead proton $\mathrm{H}-16 \mathrm{a}$ and $\mathrm{H}-11$ respectively.

In the ${ }^{1} \mathrm{H}$ NMR spectrum of the adduct $2 \mathrm{c}$ in tetradeuteriomethanol, the corresponding aromatic proton $\mathrm{H}-8$, the olefinic proton $\mathrm{H}-17$ and the two bridgehead protons $\mathrm{H}-16 \mathrm{a}$ and $\mathrm{H}-11$ appeared as a singlet at $\delta 7.01$ and as broad singlets at $\delta 6.04,5.19$ and 5.99 respectively. The presence of a three-proton singlet resonance at $\delta 2.67$ confirmed the incorporation of a methyl group attached to nitrogen.

In the ${ }^{13} \mathrm{C}$ NMR spectrum of the adduct $\mathbf{2 b}$, resonance signals for the two carbonyl carbons appeared at $\delta 156.5$ and 156.4. A quaternary carbon at $\delta 116.9$ was attributed to the cyanamide carbon while two methine carbon at $\delta 52.0$ and 55.9 were assigned to the two bridgehead carbons. In the ${ }^{13} \mathrm{C}$ NMR spectrum of the adduct $2 \mathbf{c}$, the corresponding carbonyl carbons both appeared at $\delta 157.3$ and the two bridgehead carbons appeared at $\delta 47.5$ and 67.3. The remainder of the spectra of the adducts $\mathbf{2 b - c}$ were consistent with the proposed structures.

The single adducts 2a-c which were obtained from the Diels-Alder reactions are each tentatively assigned as endo by analogy with other such adducts of 4-substituted-1,2,4-triazoline3,5-diones. ${ }^{12-14}$ In all such adducts, only the endo adducts have been observed in X-ray crystallographic studies, with the exception of the adduct of 4-methyl-1,2,4-triazoline-3,5-dione with 11-cyano-1,6-methano[10]annulene; the endo and exo adducts were isolated in this case and their configurations were confirmed by X-ray crystal structure analysis. ${ }^{14}$

It is of interest that the dienophile adds exclusively onto the less-substituted ring at the 5,8 positions in 1a-c; no addition on the dimethoxy-substituted ring at the 1,4-positions was observed. This may be a result of the steric crowding by the bridging substituent at position 1 and the 4-methoxy group. Diels-Alder cycloaddition at other positions is excluded on the basis of no aromatic ring stabilization in the products that would result; the ${ }^{1} \mathrm{H}$ NMR spectra were also not in accord with such products. 
Reaction of the 3-aza[5](1,7)naphthalenophane (1a) and 3-aza[6](1,7)naphthalenophanes (1b) and (1d) with tetracyanoethylene also proceeded smoothly under mild conditions, giving the 1:1 adducts (3a), (3b) and (3c) respectively in high yields (Scheme 2 and Table 2).<smiles>[R]N1CCCCCCCc2cc(OC)c(OC)c3ccc(cc23)CC1</smiles>

$(1 a, b, d)$
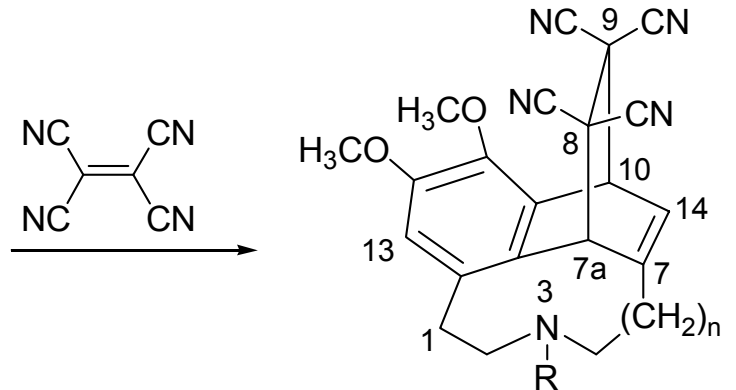

$(3 a, b, c)$

\begin{tabular}{cccc}
\hline $\mathbf{1}$ & $\mathbf{3}$ & $\mathrm{n}$ & $\mathrm{R}$ \\
\hline $\mathrm{a}$ & $\mathrm{a}$ & 1 & $\mathrm{CN}$ \\
$\mathrm{b}$ & $\mathrm{b}$ & 2 & $\mathrm{CN}$ \\
$\mathrm{d}$ & $\mathrm{c}$ & 2 & $\mathrm{COOCH}_{3}$ \\
\hline
\end{tabular}

Scheme 2

Table 2. Diels-Alder reaction of the 3-aza(1,7)naphthalenophanes (1a), (1b) and (1d) with tetracyanoethylene

\begin{tabular}{cccc}
\hline Compound & Reaction conditions & Adduct & Yield (\%) \\
\hline$(\mathbf{1 a})$ & $\mathrm{THF}, 20{ }^{\circ} \mathrm{C}, 3 \mathrm{~h}$ & $\mathbf{( 3 a )}$ & 90 \\
$(\mathbf{1 b})$ & $\mathrm{THF}, 20{ }^{\circ} \mathrm{C}, 20 \mathrm{~h}$ & $\mathbf{( 3 b )}$ & 90 \\
$(\mathbf{1 d})$ & $\mathrm{THF}, 20{ }^{\circ} \mathrm{C}, 20 \mathrm{~h}$ & $\mathbf{( 3 c )}$ & 88 \\
\hline
\end{tabular}

Structural assignments of the adducts (3a-c) were supported by spectroscopic and analytical data. The molecular formula of the adducts $\mathbf{3 a}$ and $\mathbf{3} \mathbf{c}$ were determined from high-resolution mass spectrometry and, in each case, were reinforced by elemental analysis. In the case of the adduct $\mathbf{3 b}$, the mass spectrum had an identical fragmentation pattern to that of the starting 3aza[6](1,7)naphthalenophane (1) due to a thermal retro Diels-Alder reaction of the adduct $\mathbf{3 b}$ in the mass spectrometer and no molecular ion was observed, as was the case with the adduct $\mathbf{2 b}$. A satisfactory elemental analysis on the adduct $\mathbf{3 b}$ was obtained.

The infrared spectra of the adduct 3a-b showed characteristic absorption bands at $2216 \mathrm{~cm}^{-1}$ for $\mathbf{3 a}$ and $2208 \mathrm{~cm}^{-1}$ for $\mathbf{3 b}$ indicating the presence of the cyanamide moiety, while a strong absorption band at $1698 \mathrm{~cm}^{-1}$ ascribed to the $N$-carboxylate group was observed in the infrared spectrum of the adduct $\mathbf{3 c}$.

The characteristic features of the ${ }^{1} \mathrm{H}$ NMR spectra of the adducts 3a-c were two one-proton doublets at $\delta$ values ranging from 5.45 to $5.79(J=1.2-1.5 \mathrm{~Hz})$ and at $\delta$ values ranging from 5.33 
to $5.64(J=6.2-6.3 \mathrm{~Hz})$ which were ascribed, respectively, to the bridgehead protons $\mathrm{H}-6 \mathrm{a}, \mathrm{H}-9$ in 3a and $\mathrm{H}-7 \mathrm{a}, \mathrm{H}-10$ in $\mathbf{3 b}-\mathbf{c}$. A one proton singlet at $\delta$ values ranging from 6.79 to 7.16 and a one-proton doublet of doublets centred at $\delta 6.68,6.89$ and $6.76(J=6.2-6.3$ and 1.2-1.5 Hz) were assigned to the aromatic proton $\mathrm{H}-12$ in $\mathbf{3 a}, \mathrm{H}-13$ in $\mathbf{3 b}-\mathbf{c}$ and the olefinic proton $\mathrm{H}-13$ in $\mathbf{3 a}, \mathrm{H}-$ 14 in $\mathbf{3 b}-\mathbf{c}$.

In the ${ }^{13} \mathrm{C}$ NMR spectrum of the adduct $\mathbf{3 b}$, two methine signals appeared at $\delta 45.0$ and 52.4 which were assigned to the two bridgehead carbons. Four quaternary carbon resonances at $\delta$ values ranging from $\delta 113.9$ to 113.2 were assigned to the cyanide carbons. The resonance at $\delta$ 117.5 was ascribed to the cyanamide carbon.

In the ${ }^{13} \mathrm{C}$ NMR spectrum of the adduct $3 \mathbf{c}$, the bridgehead carbons appeared at $\delta 44.9$ and 51.1 while four cyanide carbon resonances at $\delta$ values ranging from 113.9 to 113.8 and an $N$ carboxylate carbonyl carbon resonance at $\delta 158.8$ were observed. The remainder of the spectra of the adducts $\mathbf{3 b}-\mathbf{c}$ were in accord with the structures proposed.

Diels-Alder reactivity with the less electron deficient dienophile 1,1-dicyanoethylene was also investigated. In this case, reaction with $\mathbf{1 b}$ did proceed but longer reaction times were required and mixtures of the regioisomers $4 \mathbf{a}$ and $\mathbf{5 a}$ were obtained in 33\% and 59\% yield respectively (Scheme 3).<smiles></smiles>

$(4 a, b, c)$

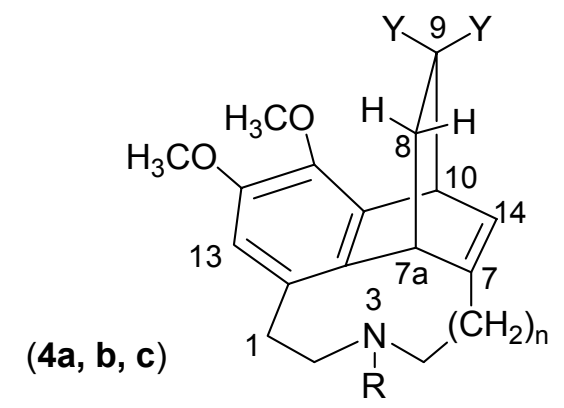<smiles>[Y]C([Y])=C[H]</smiles>

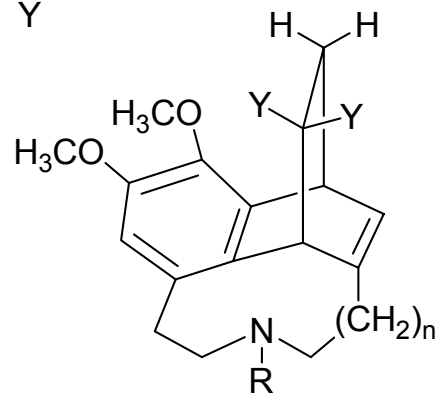

$(5 a, b, c)$

\section{Scheme 3}

\begin{tabular}{ccccc}
\hline $\mathbf{1}$ & $\mathbf{4 , 5}$ & $\mathrm{n}$ & $\mathrm{R}$ & $\mathrm{Y}$ \\
\hline $\mathbf{b}$ & $\mathbf{a}$ & 2 & $\mathrm{CN}$ & $\mathrm{CN}$ \\
$\mathbf{d}$ & $\mathbf{b}$ & 2 & $\mathrm{COOCH}_{3}$ & $\mathrm{CN}$ \\
- & $\mathbf{c}$ & 2 & $\mathrm{CN}$ & $\mathrm{COOCH}_{2} \mathrm{CH}_{3}$ \\
\hline
\end{tabular}


Table 3. Diels-Alder reaction of the 3-aza[6](1,7)naphthalenophanes (1b) and (1d) with 1,1dicyanoethylene

\begin{tabular}{cccc}
\hline Compound & Reaction conditions & Adducts & Yield (\%) \\
\hline \multirow{2}{*}{ 1b } & \multirow{2}{*}{ Benzene, $20{ }^{\circ} \mathrm{C}, 23 \mathrm{~h}$} & $\mathbf{4 a}$ & 33 \\
& & $\mathbf{5 a}$ & 59 \\
\multirow{2}{*}{ 1d } & Benzene, $20{ }^{\circ} \mathrm{C}, 48 \mathrm{~h}$ & $\mathbf{4 b}$ & 12 \\
& & $\mathbf{5 b}$ & 10 \\
\hline
\end{tabular}

${ }^{\dagger}$ In this table and in others given in this paper, the percentage yield refers to the mole percentage yield of that product.

Similarly, reaction of the 3-aza[6](1,7)naphthalenophane (1d) with 1,1-dicyanoethylene in benzene at room temperature for 48 hours gave, after p.t.l.c., the regioisomeric adducts (4b) and (5b) together with unchanged (1d) in 12\%, 10\% and 42\% yield respectively (Scheme 3 and Table 3).

The reduced yields of the adducts $\mathbf{4 b}$ and $\mathbf{5 b}$ compared with those of the analogous adducts 4a and 5a, may be attributed to their slower rate of formation; indeed, a substantial amount of starting naphthalenophane (1d) was recovered from the reaction of $\mathbf{1 d}$ with 1,1-dicyanoethylene.

The structural assignment of the adducts $\mathbf{4}$ and $\mathbf{5}$ rested on analytical and spectroscopic evidence. Microanalyses of the adducts $4 \mathbf{a}$ and $\mathbf{5 a}$ indicated an empirical formula of $\mathrm{C}_{22} \mathrm{H}_{22} \mathrm{~N}_{4} \mathrm{O}_{2}$ and this was shown to be the molecular formula for both regioisomeric adducts from highresolution mass spectrometry. A strong absorption band at $2208 \mathrm{~cm}^{-1}$, indicative of cyanamide functionality, together with a weak absorption band at $2248 \mathrm{~cm}^{-1}$ attributed to the nitrile group, were present in the infrared spectra of both adducts.

In the ${ }^{1} \mathrm{H}$ NMR spectrum of $\mathbf{4 a}$, a one-proton triplet of doublets centred at $\delta 4.35\left(J_{\mathrm{t}}=3.0 \mathrm{~Hz}\right.$, $J_{\mathrm{d}}=1.6 \mathrm{~Hz}$ ) and a one-proton singlet at $\delta 6.52$ were assigned to the bridgehead proton $\mathrm{H}-7 \mathrm{a}$ and the aromatic proton $\mathrm{H}-13$ respectively while the bridgehead proton $\mathrm{H}-10$ and the aromatic proton $\mathrm{H}-14$ appeared at $\delta 4.97(\mathrm{~d}, J=6.1 \mathrm{~Hz})$ and at $\delta 6.26(\mathrm{br} . \mathrm{d}, J=6.1 \mathrm{~Hz})$ respectively. The methylene protons $\mathrm{H}-8$ adjacent to the bridgehead carbon $\mathrm{C}-7 \mathrm{a}$ appeared as an $\mathrm{AB}$ quartet of doublets centred at $\delta 2.43$ and $\delta 2.32$ indicating geminal coupling $(J=13.2 \mathrm{~Hz})$ and vicinal coupling $(J=3.0 \mathrm{~Hz})$. The remainder of the spectrum was consistent with the proposed structure.

In the ${ }^{1} \mathrm{H}$ NMR spectrum of the adduct 5a, a one-proton doublet of triplets centred at $\delta 4.64$ $\left(J_{\mathrm{d}}=6.4 \mathrm{~Hz}, J_{\mathrm{t}}=2.6 \mathrm{~Hz}\right)$ and a one-proton singlet at $\delta 6.51$ were ascribed to the bridgehead proton $\mathrm{H}-10$ and the aromatic proton $\mathrm{H}-13$ respectively, while the bridgehead proton $\mathrm{H}-7 \mathrm{a}$ and the olefinic proton $\mathrm{H}-14$ appeared as a doublet at $\delta 4.80(J=1.5 \mathrm{~Hz})$ and a broad doublet at $\delta$ $6.47(J=6.4 \mathrm{~Hz})$ respectively. The methylene proton $\mathrm{H}-9$ adjacent to the bridgehead carbon C10 appeared as an AB quartet of doublets centred at $\delta 2.48$ and 2.28 indicating geminal coupling $(J=13.0 \mathrm{~Hz})$ and vicinal coupling $(J=2.6 \mathrm{~Hz})$. 
The ${ }^{13} \mathrm{C}$ NMR spectrum of the adduct $4 \mathbf{a}$ was also in accord with the proposed structure. The methylene carbon (C-8) adjacent to the bridgehead (C-7a) appeared at $\delta 41.1$ and two bridgehead carbons $(\mathrm{C}-7 \mathrm{a})$ and $(\mathrm{C}-10)$ appeared at $\delta 43.1$ and 42.8 , respectively.

In the case of the adducts $\mathbf{4 b}$ and $\mathbf{5 b}$, the molecular formula, $\mathrm{C}_{23} \mathrm{H}_{25} \mathrm{~N}_{3} \mathrm{O}_{5}$, for both compounds was again established from high-resolution mass spectrometry and this was supported by elemental analyses. A strong absorption band at $1698 \mathrm{~cm}^{-1}$ for $4 \mathbf{b}$ and at $1700 \mathrm{~cm}^{-1}$ for $\mathbf{5 b}$ in the infrared spectra confirmed the presence of the $N$-carboxylate carbonyl group.

In the ${ }^{1} \mathrm{H}$ NMR spectrum of the adduct $\mathbf{4 b}$, a one-proton triplet of doublets centred at $\delta 4.20$ $\left(J_{\mathrm{t}}=2.6 \mathrm{~Hz}, J_{\mathrm{d}}=1.5 \mathrm{~Hz}\right)$ and a one-proton doublet at $\delta 4.92(J=6.1 \mathrm{~Hz})$ were assigned to the bridgehead proton $\mathrm{H}-7 \mathrm{a}$ and $\mathrm{H}-10$ respectively, while the aromatic proton $\mathrm{H}-13$ and the olefinic proton $\mathrm{H}-14$ appeared as a singlet at $\delta 6.51$ and a broad doublet at $\delta 6.18(\mathrm{~J}=5.9 \mathrm{~Hz})$ respectively. The methylene protons $\mathrm{H}-8$ adjacent to the bridgehead carbon $\mathrm{C}-7 \mathrm{a}$ appeared as an $\mathrm{AB}$ quartet of doublets centred at $\delta 2.38$ and 2.26 indicative of geminal coupling $(J=12.9 \mathrm{~Hz})$ and vicinal coupling $(J=2.6 \mathrm{~Hz})$.

In the ${ }^{1} \mathrm{H}$ NMR spectrum of the adduct $\mathbf{5 b}$, a one-proton doublet of triplets centred at $\delta 4.46$ $\left(J_{\mathrm{d}}=6.3 \mathrm{~Hz}, J_{\mathrm{t}}=2.6 \mathrm{~Hz}\right)$ and a one-proton doublet at $\delta 4.69(J=1.5 \mathrm{~Hz})$ were assigned to the bridgehead proton $\mathrm{H}-7 \mathrm{a}$ and $\mathrm{H}-10$ respectively, while the aromatic proton $\mathrm{H}-13$ and the olefinic proton $\mathrm{H}-14$ appeared as a singlet at $\delta 6.51$ and a broad doublet at $\delta 6.41(\mathrm{~J}=6.2 \mathrm{~Hz})$ respectively. The methylene protons H-9 adjacent to the bridgehead carbon C-10 appeared as an $\mathrm{AB}$ quartet of doublets centred at $\delta 2.47$ and 2.32 indicative of geminal coupling $(J=12.8 \mathrm{~Hz})$ and vicinal coupling $(J=2.6 \mathrm{~Hz})$.

Analogous product patterns were observed with 1a and the diester 1,1-diethyl methylene malonate, affording the polycyclic adducts $\mathbf{4 c}$ and $\mathbf{5 c}$ with ester functionality.

\section{Conclusions}

The 3-aza[5](1,7)naphthalenophane 1a showed facile and selective dienophilic reactivity in the Diels-Alder reaction with electron deficient dienophiles. The 3-aza[6](1,7)naphthalenophanes 1b-d reacted similarly but were not as diene-like consistent with less naphthalene ring distortion with the longer bridging chain. The Diels-Alder reaction in these systems provided ready access to new rigid polycyclic heterocyclic systems with a range of functionalities which should be capable of further manipulation.

\section{Experimental Section}

General Procedures. Elemental analyses were performed by the Canadian Microanalytical Service Ltd, Vancouver, Canada. Melting points were determined on a Yanagimoto Seisakusho micro-melting point apparatus, and are uncorrected. 
Mass spectra were determined on VG MM 7070F mass spectrometer operating at $70 \mathrm{eV}$, with source temperature of $200{ }^{\circ} \mathrm{C}$ (direct insertion); peak intensities, in parentheses, are expressed as a percentage of the base peak. ${ }^{1} \mathrm{H}$ nuclear magnetic resonance spectra were determined at 300 $\mathrm{MHz}$ with a Bruker AM-300 spectrometer, tetramethylsilane being used as internal standard. ${ }^{13} \mathrm{C}$ NMR spectra were recorded at $75.5 \mathrm{MHz}$ with a Bruker AM-300 spectrometer; assignments indicated by superscript letters may be interchanged for carbon atoms within each group defined by these letters. NMR spectra were determined in $\mathrm{CDCl}_{3}$ as solvent unless otherwise stated. Infrared spectra were recorded on a Hitachi 270-30 infrared spectrophotometer.

$R_{\mathrm{f}}$ values refer to thin-layer chromatography on Merck silica gel $60 \mathrm{~F}_{254}$. Preparative thinlayer chromatography and column chromatography were performed on Camag silica gel.

All chromatographic solvent proportions are volume for volume. Solvents were removed under reduce pressure in a rotary evaporator; the drying of the organic solvent extracts was done with anhydrous sodium sulfate. Light petroleum used had a b.p. range of $40-60{ }^{\circ} \mathrm{C}$.

\section{2,3,5,6,10,13,14,15a-Octahydro-8,9-dimethoxy-12,14-dioxo-13-phenyl-4H-10,1-metheno- $12 H$-[1,2,4]triazolo[1',2':1,2]pyridazino[3,4,5-gh][3]benzazonine-4-carbonitrile (2a). To a} stirred solution of benzeneseleninic anhydride $(0.081 \mathrm{~g}, 0.225 \mathrm{mmol})$ in dry tetrahydrofuran $(8$ $\mathrm{mL})$ was added in one portion 4-phenyl-1,2,4-triazolidine-3,5-dione $(0.120 \mathrm{~g}, 0.678 \mathrm{mmol})$ and the 3-aza[5](1,7)naphthalenophane (1a) $(0.175 \mathrm{~g}, 0.6205 \mathrm{mmol})$. After stirring $2 \mathrm{~h}$ at room temperature under nitrogen, the solution was evaporated to dryness and the residue was subjected to p.t.l.c. (chloroform/10\% ethyl acetate) to yield $\left(R_{\mathrm{f}} 0.28\right)$, after recrystallization from ethyl acetate/n-hexane, the adduct $\mathbf{2 a}(233 \mathrm{mg}, 0.510 \mathrm{mmol}, 82 \%)$ as colourless prisms, m.p. 212-213 ${ }^{\circ} \mathrm{C}$. (Found: $\mathrm{C}, 65.5 ; \mathrm{H}, 5.1 ; \mathrm{N}, 15.3 . \mathrm{C}_{25} \mathrm{H}_{23} \mathrm{~N}_{5} \mathrm{O}_{4}$ requires $\mathrm{C}, 65.5 ; \mathrm{H}, 5.1, \mathrm{~N}, 15.3 \%$ ). Mass spectrum: $m / z 457\left(\mathrm{M}^{+}, 30\right.$, accurate mass 457.1761. $\mathrm{C}_{25} \mathrm{H}_{23} \mathrm{~N}_{5} \mathrm{O}_{4}$ requires 457.1747), 282 (100), 251 (50), 213 (50), 119 (40). ${ }^{1} \mathrm{H}$ NMR $\left(50{ }^{\circ} \mathrm{C}\right): \delta 7.45-7.30(5 \mathrm{H}, \mathrm{m}, \mathrm{N}-\mathrm{Ph}), 6.54(1 \mathrm{H}, \mathrm{d}, J 5.7, \mathrm{H}-$ 16), 6.44 (1H, s, H-7), 6.20 (1H, d, J 5.7, H-10), 6.08 (1H, s, H-15a), 3.91 (3H, s, OCH $), 3.83$ $\left(3 \mathrm{H}, \mathrm{s}, \mathrm{OCH}_{3}\right), 3.80-3.63(1 \mathrm{H}, \mathrm{m}, \mathrm{H}-1), 3.63-3.48(1 \mathrm{H}, \mathrm{m}), 3.41-3.31(1 \mathrm{H}, \mathrm{m}), 2.95-2.80(1 \mathrm{H}$, $\mathrm{m}), 2.78-2.54(2 \mathrm{H}, \mathrm{m}), 2.54-2.40(1 \mathrm{H}, \mathrm{m}), 1.27-1.16(1 \mathrm{H}, \mathrm{m}) .{ }^{13} \mathrm{C}$ NMR: $\delta 156.2,142.1,143.8$, $131.4,128.9,128.1,125.1,116.1,110.0,62.2,57.0,55.8,55.3,50.9,33.4,31.9$. IR $v_{\max }$ (Nujol mull): 2204 (sharp, m, CN), 1770, 1712 (sharp, $\mathrm{C}=\mathrm{O}$ ) $\mathrm{cm}^{-1}$.

\section{3,4,6,7,11,14,15,16a-Octahydro-9,10-dimethoxy-13,15-dioxo-14-phenyl-11,1-metheno-13H-} $[1,2,4]$ triazolo[1',2':2,3]phthalazino[8,1-de]azecine-5(2H)-carbonitrile (2b). To a stirred solution of benzeneseleninic anhydride $(0.104 \mathrm{~g}, 0.289 \mathrm{mmol})$ in dry tetrahydrofuran $(10 \mathrm{~mL})$ was added in one portion 4-phenyl-1,2,4-triazolidine-3,5-dione $(0.143 \mathrm{~g}, 0.807 \mathrm{mmol})$ and the 3aza[6](1,7)naphthalenophane (1b) $(0.232 \mathrm{~g}, 0.784 \mathrm{mmol})$. After stirring $4 \mathrm{~h}$ at room temperature under nitrogen, the solution was evaporated to dryness and the residue was subjected to p.t.l.c. (chloroform/10\% ethyl acetate) to yield $\left(R_{\mathrm{f}} 0.16\right)$, after recrystallization from ethyl acetate/nhexane, the adduct $\mathbf{2 b}(288 \mathrm{mg}, 0.611 \mathrm{mmol}, 78 \%)$ as colourless prisms, m.p. 202-203 ${ }^{\circ} \mathrm{C}$. (Found: $\mathrm{C}, 66.1 ; \mathrm{H}, 5.3 ; \mathrm{N}, 14.8 . \mathrm{C}_{26} \mathrm{H}_{25} \mathrm{~N}_{5} \mathrm{O}_{4}$ requires $\mathrm{C}, 66.2 ; \mathrm{H}, 5.3 ; \mathrm{N}, 14.9 \%$ ). Mass spectrum: $m / z 296\left(\mathrm{M}^{+} \cdot-\mathrm{C}_{8} \mathrm{H}_{5} \mathrm{~N}_{3} \mathrm{O}_{2}, 60\right), 285$ (18), 281 (10), 227 (100), 214 (30), 199 (10), 119 
(20). $\left(\mathrm{CH}_{4} \mathrm{CI}: 296\left(\mathrm{M}^{+} \cdot-\mathrm{C}_{8} \mathrm{H}_{5} \mathrm{~N}_{3} \mathrm{O}_{2}, 100\right), 270\right.$ (90), 227 (60), 178 (85), 119 (50), 57 (40)). ${ }^{1} \mathrm{H}$ NMR: $\delta$ 7.43-7.29 (5H, m, N-Ph), $6.55(1 \mathrm{H}, \mathrm{dd}, J 5.9,1.6, \mathrm{H}-17), 6.51(1 \mathrm{H}, \mathrm{s}, \mathrm{H}-8), 6.23(1 \mathrm{H}, \mathrm{d}$, $J$ 5.9, H-11), $6.01(1 \mathrm{H}, \mathrm{d}, J 1.6, \mathrm{H}-16 \mathrm{a}), 3.91\left(3 \mathrm{H}, \mathrm{s}, \mathrm{OCH}_{3}\right), 3.84\left(3 \mathrm{H}, \mathrm{s}, \mathrm{OCH}_{3}\right), 3.76-3.64(1 \mathrm{H}$, $\mathrm{m}), 3.40-3.27(1 \mathrm{H}, \mathrm{m}), 2.97-2.85(2 \mathrm{H}, \mathrm{m}), 2.76-2.54(3 \mathrm{H}, \mathrm{m}), 2.20-1.90(2 \mathrm{H}, \mathrm{m}), 1.57-1.40(1 \mathrm{H}$, m). ${ }^{13} \mathrm{C}$ NMR: $\delta 156.5$ (CO), 156.4 (CO), 142.5 (C9), 149.3 (C10), 142.9, 131.4, 130.2, 129.4, $129.0(2 \times \mathrm{ArCH}), 128.9,128.2(\mathrm{C} 8), 128.1(\mathrm{ArCH}), 125.2(2 \mathrm{x} \mathrm{ArCH}), 116.9(\mathrm{CN}), 110.6$

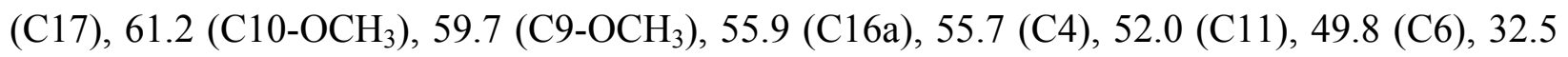
$(\mathrm{C} 3)^{\mathrm{a}}, 28.7(\mathrm{C} 7)^{\mathrm{a}}, 27.5$ (C2). IR $v_{\max }$ (Nujol mull): 2208 (sharp, s, CN), 1770, 1716 (sharp, c, $\mathrm{C}=\mathrm{O}) \mathrm{cm}^{-1}$.

3,4,6,7,11,14,15,16a-Octahydro-9,10-dimethoxy-5(2H)-methyl-13,15-dioxo-14-phenyl-11,1metheno-13H-[1,2,4]triazolo[1',2':2,3]phthalazino[8,1-de]azecine (2c). To a stirred solution of benzeneseleninic anhydride $(97 \mathrm{mg}, 0.269 \mathrm{mmol})$ in dry tetrahydrofuran $(10 \mathrm{~mL})$ was added in one portion 4-phenyl-1,2,4-triazolidine-3,5-dione (150 $\mathrm{mg}, 0.845 \mathrm{mmol})$ and the 3aza[6](1,7)naphthalenophane (1c) $(226 \mathrm{mg}, 0.793 \mathrm{mmol})$. After stirring $3.5 \mathrm{~h}$ at room temperature under nitrogen, the solution was evaporated to dryness. To the residue was added light petroleum $(50 \mathrm{~mL})$ and then filtered. The crude solid was recrystallized from methanol/light petroleum/ethyl acetate to afford the adduct $2 \mathrm{c}(254 \mathrm{mg}, 0.552 \mathrm{mmol}, 70 \%)$ as colourless prisms, m.p. $133-135{ }^{\circ} \mathrm{C}(\mathrm{dec})$. (Found: C, 64.3; H, 6.0; N, 12.0. $\mathrm{C}_{26} \mathrm{H}_{28} \mathrm{~N}_{4} \mathrm{O}_{4} .1 .25$ $\mathrm{H}_{2} \mathrm{O}$ requires $\mathrm{C}$, 64.6; $\left.\mathrm{H}, 6.1 ; \mathrm{N}, 11.6 \%\right)$. Mass spectrum: $m / z 269\left(\mathrm{M}^{+} \cdot-\mathrm{C}_{9} \mathrm{H}_{9} \mathrm{~N}_{3} \mathrm{O}_{2}, 100\right.$, accurate mass 269.1430. $\mathrm{C}_{17} \mathrm{H}_{19} \mathrm{NO}_{2}$, requires 269.1414), 254 (80), 226 (15), 191 (30), 119 (20). ${ }^{1} \mathrm{H}$ NMR (CD $\left.3 \mathrm{OD}\right): \delta 7.45(2 \mathrm{H}, \mathrm{s}, 2 \mathrm{ArH}), 7.44(2 \mathrm{H}, \mathrm{s}, 2 \mathrm{ArH}), 7.37-7.28(1 \mathrm{H}, \mathrm{m}, \mathrm{ArH}), 7.01(1 \mathrm{H}$, s, H-8), 6.04 (1H, br s, H-17), 5.99 (1H, br s, H-11), 5.19 (1H, br s, H-16a), $3.87\left(3 \mathrm{H}, \mathrm{s}, \mathrm{OCH}_{3}\right)$, $3.71\left(3 \mathrm{H}, \mathrm{s}, \mathrm{OCH}_{3}\right), 3.97-3.90(1 \mathrm{H}, \mathrm{m}), 3.77-3.70(3 \mathrm{H}, \mathrm{m}), 3.34-3.25(2 \mathrm{H}, \mathrm{m}), 2.75-2.50(2 \mathrm{H}, \mathrm{m})$, $2.67\left(3 \mathrm{H}, \mathrm{s}, \mathrm{NCH}_{3}\right), 2.35-2.08(1 \mathrm{H}, \mathrm{m}), 2.10-1.96(1 \mathrm{H}, \mathrm{m}) .{ }^{13} \mathrm{C} \mathrm{NMR}\left(\mathrm{CD}_{3} \mathrm{OD}\right): \delta 157.3(2 \mathrm{CO})$, 155.1 (C9), 153.4 (C10), 147.7, 135.7, 131.7 (2C), 130.2 (2ArH), 128.7 (ArH), 128.5 (ArH), $128.0(2 \mathrm{ArH}), 120.2,114.2$ (C8), 67.3 (C16a), 65.8 (C6), $62.4(\mathrm{C} 4), 60.9\left(\mathrm{C} 10-\mathrm{OCH}_{3}\right), 56.7$ (C9$\left.\mathrm{OCH}_{3}\right), 47.5(\mathrm{C} 11), 40.8\left(\mathrm{NCH}_{3}\right), 30.9(\mathrm{C} 7), 25.0$ (C3), $20.8(\mathrm{C} 2)$. IRv $v_{\max }$ (Nujol mull): 1702, 1688 (sharp, $\mathrm{s}, \mathrm{C}=\mathrm{O}) \mathrm{cm}^{-1}$.

\section{7,7,8,8-Tetracyano-1,2,4,5,6a,9-hexahydro-10,11-dimethoxy-9,6-metheno-6H-benzo[1,2,3-}

gh][3]benzazonine-3-carbonitrile (3a). To a stirred solution of tetracyanoethylene (90 $\mathrm{mg}$, $0.699 \mathrm{mmol})$ in dry tetrahydrofuran $(8 \mathrm{~mL})$ was added the 3-aza[5](1,7)naphthalenophane (1a) (174 mg, $0.617 \mathrm{mmol}$ ) under nitrogen at $0{ }^{\circ} \mathrm{C}$. The mixture was stirred at room temperature for 3 h. The precipitate which formed was collected by filtration and recrystallized from acetronitrile $/ n$-hexane to yield the adduct 3a (249 $\mathrm{mg}, 0.607 \mathrm{mmol}, 98 \%)$ as colourless prisms, m.p. $250-252{ }^{\circ} \mathrm{C}$. (Found: C, 66.8; H, 4.4; N, 20.3. $\mathrm{C}_{23} \mathrm{H}_{18} \mathrm{~N}_{6} \mathrm{O}_{2}$ requires $\mathrm{C}, 67.3 ; \mathrm{H}, 4.4 ; \mathrm{N}$, 20.5\%). Mass spectrum: $m / z 410\left(\mathrm{M}^{+}, 6\right.$, accurate mass 410.1510. $\mathrm{C}_{23} \mathrm{H}_{18} \mathrm{~N}_{6} \mathrm{O}_{2}$, requires 410.1489), 282 (100), 281 (25), 251 (50), 213 (50), 128 (92), 76 (72). ${ }^{1} \mathrm{H}$ NMR $\left(\mathrm{CDCl}_{3} / \mathrm{CD}_{3} \mathrm{COCD}_{3}\right): \delta 6.79(1 \mathrm{H}, \mathrm{s}, \mathrm{H}-12), 6.68(1 \mathrm{H}, \mathrm{dd}, J 6.2,1.2, \mathrm{H}-13), 5.45(1 \mathrm{H}, \mathrm{d}, J 1.2, \mathrm{H}-$ 6a), 5.33 (1H, d, J 6.2, H-9), $3.97\left(3 \mathrm{H}, \mathrm{s}, \mathrm{OCH}_{3}\right), 3.89\left(3 \mathrm{H}, \mathrm{s}, \mathrm{OCH}_{3}\right), 3.82-2.10(8 \mathrm{H}, \mathrm{m}, 4 \mathrm{x}$ $\left.\mathrm{CH}_{2}\right) .{ }^{13} \mathrm{C} \mathrm{NMR}\left(\mathrm{CD}_{3} \mathrm{CN}\right): \delta 152.5,149.1,144.9,130.3,127.7,125.4,117.1,113.5,112.3(2 \mathrm{CN})$, 
$112.1,111.8,60.9,60.0,55.5,54.1,53.5,48.6,44.9,43.9,43.1,30.5,28.8$. IR $v_{\max }$ (Nujol mull): 2216 (sharp, s, CN) $\mathrm{cm}^{-1}$.

8,8,9,9-Tetracyano-1,4,5,6,7a,10-hexahydro-11,12-dimethoxy-10,7-metheno-7H-naphth[1,8de]azecine-3(2H)-carbonitrile (3b). To a stirred solution of tetracyanoethylene (130 $\mathrm{mg}, 1.01$ mmol) in dry tetrahydrofuran $(10 \mathrm{~mL})$, cooled in ice bath, was added the 3aza[6](1,7)naphthalenophane (1b) $(300 \mathrm{mg}, 1.01 \mathrm{mmol})$ under nitrogen. The mixture was stirred at room temperature for $20 \mathrm{~h}$. The precipitate which formed was collected and recrystallized from dichrolomethane/light petroleum to afford the adduct $\mathbf{3 b}(385 \mathrm{mg}, 0.908 \mathrm{mmol}, 90 \%)$ as colourless prisms, m.p. $215-217{ }^{\circ} \mathrm{C}$. (Found: $\mathrm{C}, 68.0 ; \mathrm{H}, 4.8 ; \mathrm{N}, 19.8 . \mathrm{C}_{24} \mathrm{H}_{20} \mathrm{~N}_{6} \mathrm{O}_{2}$ requires $\mathrm{C}$, 67.9; H, 4.8; N, 19.8\%). Mass spectrum: $m / z 410\left(\mathrm{M}^{+} \cdot-\mathrm{C}_{6} \mathrm{H}_{4}, 72\right), 227$ (100), 214 (35), 128 (90), $76(85) .{ }^{1} \mathrm{H}$ NMR $\left(\mathrm{CD}_{3} \mathrm{COCD}_{3}\right): \delta 7.16(1 \mathrm{H}, \mathrm{s}, \mathrm{H}-13), 6.89(1 \mathrm{H}, \mathrm{dd}, J 6.3,1.3, \mathrm{H}-14), 5.79(1 \mathrm{H}$, d, $J 1.3, \mathrm{H}-7 \mathrm{a}), 5.64(1 \mathrm{H}, \mathrm{d}, J 6.3, \mathrm{H}-10), 4.10\left(3 \mathrm{H}, \mathrm{s}, \mathrm{OCH}_{3}\right), 4.05\left(3 \mathrm{H}, \mathrm{s}, \mathrm{OCH}_{3}\right), 3.83-3.71(2 \mathrm{H}$, $\mathrm{m}), 3.30-3.23(2 \mathrm{H}, \mathrm{m}), 3.01-2.94(2 \mathrm{H}, \mathrm{m}), 2.73-2.68(1 \mathrm{H}, \mathrm{m}), 2.48-2.32(1 \mathrm{H}, \mathrm{m}), 2.26-2.15(1 \mathrm{H}$, m), 1.82-1.69 (2H, m). ${ }^{13} \mathrm{C}$ NMR $\left(\mathrm{CD}_{3} \mathrm{COCD}_{3}\right): \delta 154.0$ (C12), $151.9(\mathrm{C} 11), 145.9,133.8,130.2$ (C14), 129.4, 128.7, $117.5(\mathrm{~N}-\mathrm{CN}), 114.3(\mathrm{C} 13), 113.9(\mathrm{CN}), 113.7(\mathrm{CN}), 113.6(\mathrm{CN}), 113.2$ $(\mathrm{CN}), 62.0\left(\mathrm{C} 11-\mathrm{OCH}_{3}\right), 56.9(\mathrm{C} 4), 56.7\left(\mathrm{C} 12-\mathrm{OCH}_{3}\right), 55.3(\mathrm{C} 9), 52.4(\mathrm{C} 7 \mathrm{a}), 50.6(\mathrm{C} 2), 46.4$ (C8), 45.0 (C10), 32.3 (C5), 31.4 (C1), 28.6 (C6). IRv $v_{\max }$ (Nujol mull): 2208 (sharp, s, CN) cm ${ }^{-1}$.

Methyl 8,8,9,9-tetracyano-1,4,5,6,7a,10-hexahydro-11,12-dimethoxy-10,7-metheno-7Hnaphth[1,8-de]azecine-3(2H)-carboxylate (3c). To a stirred solution of tetracyanoethylene (117 $\mathrm{mg}, 0.912 \mathrm{mmol})$ in dry tetrahydrofuran $(10 \mathrm{~mL})$, cooled in an ice bath, was added the 3aza[6](1,7)naphthalenophane (1d) $(300 \mathrm{mg}, 0.912 \mathrm{mmol})$ under nitrogen. The mixture was stirred at room temperature for $20 \mathrm{~h}$, then evaporated to dryness. The residue was recrystallized from ethyl acetate/light petroleum to afford the adduct 3c (368 $\mathrm{mg}, 0.804 \mathrm{mmol}, 88 \%)$ as pale yellow prisms, m.p. 192-194 ${ }^{\circ} \mathrm{C}$. (Found: $\mathrm{C}$, 65.4; H, 5.2; N, 15.0. $\mathrm{C}_{25} \mathrm{H}_{23} \mathrm{~N}_{5} \mathrm{O}_{4}$ requires $\mathrm{C}, 65.6$; $\mathrm{H}, 5.1$; N, 15.3\%). Mass spectrum: $m / z 329\left(\mathrm{M}^{+} \cdot-\mathrm{C}_{6} \mathrm{H}_{4}, 55\right), 314$ (10), 227 (100), 128 (38), 102 (35), 76 (28). ${ }^{1} \mathrm{H}$ NMR $\left(\mathrm{CD}_{3} \mathrm{COCD}_{3}\right): \delta 7.11(1 \mathrm{H}, \mathrm{s}, \mathrm{H}-13), 6.76(1 \mathrm{H}, \mathrm{dd}, J 6.2,1.5, \mathrm{H}-14), 5.63$ $(1 \mathrm{H}, \mathrm{d}, J 1.5, \mathrm{H}-7 \mathrm{a}), 5.58(1 \mathrm{H}, \mathrm{d}, J 6.2, \mathrm{H}-10), 4.10\left(3 \mathrm{H}, \mathrm{s}, \mathrm{OCH}_{3}\right), 4.06\left(3 \mathrm{H}, \mathrm{s}, \mathrm{OCH}_{3}\right), 4.02-3.96$ $(1 \mathrm{H}, \mathrm{m}), 3.63-3.56(1 \mathrm{H}, \mathrm{m}), 3.614\left(3 \mathrm{H}, \mathrm{s}, \mathrm{COOCH}_{3}\right), 3.38-3.27(1 \mathrm{H}, \mathrm{m}), 3.23-3.16(1 \mathrm{H}, \mathrm{m})$, 3.01-2.69 (5H, m), 1.72-1.66 (1H, m). ${ }^{13} \mathrm{C}$ NMR $\left(\mathrm{CD}_{3} \mathrm{COCD}_{3}\right): \delta 158.8(\mathrm{CO}), 153.9(\mathrm{C} 12), 153.1$ (C11), 145.6, 134.9, 128.9, 128.8 (C14), 128.5, 114.7 (C13), 113.9 (CN), 113.7 (CN), 113.6 $(\mathrm{CN}), 113.2(\mathrm{CN}), 61.9\left(\mathrm{C} 11-\mathrm{OCH}_{3}\right), 56.6\left(\mathrm{C} 12-\mathrm{OCH}_{3}\right), 53.8(\mathrm{C} 4), 53.0\left(\mathrm{COOCH}_{3}\right), 51.2(\mathrm{C} 2)$, 51.1 (C7a), 46.9 (C9), 46.2 (C8), 44.9 (C10), 33.3 (C5), 31.9 (C1), 29.7 (C6). IRv $v_{\max }$ (Nujol mull): 1698 (sharp, s, $\mathrm{C}=\mathrm{O}$ ) $\mathrm{cm}^{-1}$; the $\mathrm{CN}$ stretching vibrations were not observed.

\section{Reaction of the 3-Aza[6](1,7)naphthalenophane (1b) with 1,1-Dicyanoethylene}

To a stirred solution of the 3-aza[6](1,7)naphthalenophane (1b) (115 mg, $0.389 \mathrm{mmol})$ in dry benzene $(5 \mathrm{~mL})$ was added a solution of 1,1-dicyanoethylene $(35 \mathrm{mg}, 0.449 \mathrm{mmol})$ in dry benzene $(1 \mathrm{~mL})$. The solution was stirred under nitrogen at room temperature for $23 \mathrm{~h}$. The solvent was evaporated to dryness. The residue was dissolved in chloroform and subjected to p.t.l.c. (toluene/2\% isopropanol; 7 developments) to give two fractions. 


\section{9,9-Dicyano-1,3,4,5,6,7a,8,10-octahydro-11,12-dimethoxy-10,7-metheno-7H-naphth[1,8-}

$\boldsymbol{d e}$ ]azecine-3-carbonitrile (4a). Fraction $1\left(R_{\mathrm{f}} 0.60\right)$ yielded the adduct $4 \mathbf{a}(48 \mathrm{mg}, 0.128 \mathrm{mmol}$, $33 \%$ ) as colourless prisms from diethyl ether, m.p. $167-169{ }^{\circ} \mathrm{C}$. (Found: C, 70.5; H, 6.0; N, 14.8 . $\mathrm{C}_{22} \mathrm{H}_{22} \mathrm{~N}_{4} \mathrm{O}_{2}$ requires $\left.\mathrm{C}, 70.6 ; \mathrm{H}, 5.9 ; \mathrm{N}, 15.0 \%\right)$. Mass spectrum: $m / z 374\left(\mathrm{M}^{+}, 1\right.$, accurate mass 374.1742. $\mathrm{C}_{22} \mathrm{H}_{22} \mathrm{~N}_{4} \mathrm{O}_{2}$ requires 374.1741), 296 (70), 295 (25), 227 (100), 214 (35). ${ }^{1} \mathrm{H}$ NMR: $\delta$ 6.52 (1H, s, H-13), 6.26 (1H, br d, J 6.1, H-14), 4.97 (1H, d, J 6.1, H-10), 4.35 (1H, td, J 3.0, 1.6, $\mathrm{H}-7 \mathrm{a}), 3.97\left(3 \mathrm{H}, \mathrm{s}, \mathrm{C} 11-\mathrm{OCH}_{3}\right), 3.84\left(3 \mathrm{H}, \mathrm{s}, \mathrm{C} 12-\mathrm{OCH}_{3}\right), 3.80-3.71(1 \mathrm{H}, \mathrm{m}), 3.35-3.21(1 \mathrm{H}, \mathrm{m})$, 2.93-2.84 (2H, m), 2.74-2.30 (3H, m), 2.43, $2.32\left(2 \mathrm{H}, \mathrm{AB}\right.$ q of d, $\left.J_{\mathrm{g}} 13.2, J_{\mathrm{v}} 3.0, \mathrm{H}-8\right), 2.17-2.00$ $(1 \mathrm{H}, \mathrm{m}), 2.10-1.79(1 \mathrm{H}, \mathrm{m}), 1.48-1.27(1 \mathrm{H}, \mathrm{m}) .{ }^{13} \mathrm{C} \mathrm{NMR}: \delta 154.40$ (C11), 152.0 (C12), 145.3

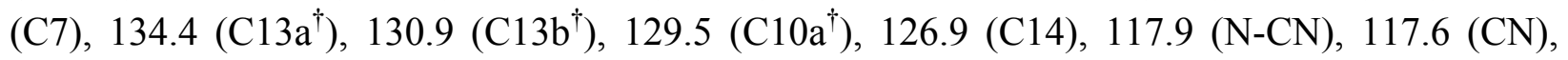

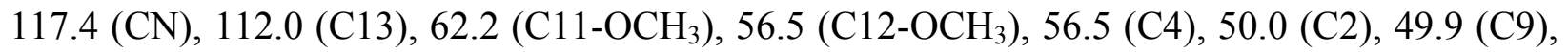

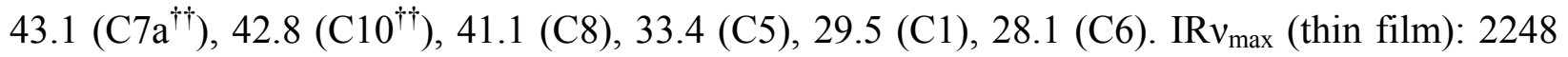
(w, CN), 2208 (sharp, s, N-CN) $\mathrm{cm}^{-1}$.

8,8-Dicyano-1,3,4,5,6,7a,9,10-octahydro-11,12-dimethoxy-10,7-metheno-7H-naphth[1,8de]azecine-3-carbonitrile (5a). Fraction $2\left(R_{\mathrm{f}} 0.50\right)$ yielded the adduct 5a $(86 \mathrm{mg}, 0.230 \mathrm{mmol}$, $59 \%$ ) as colourless prisms from diethyl ether, m.p. $163-164{ }^{\circ} \mathrm{C}$. (Found: C, 70.2; H, 6.0; N, 14.6. $\mathrm{C}_{22} \mathrm{H}_{22} \mathrm{~N}_{4} \mathrm{O}_{2}$ requires $\left.\mathrm{C}, 70.6 ; \mathrm{H}, 5.9 ; \mathrm{N}, 15.0 \%\right)$. Mass spectrum: $m / z 374\left(\mathrm{M}^{+}, 1\right.$, accurate mass 374.1742. $\mathrm{C}_{22} \mathrm{H}_{22} \mathrm{~N}_{4} \mathrm{O}_{2}$ requires 374.1741), 296 (80), 259 (28), 227 (100), 214 (38). ${ }^{1} \mathrm{H}$ NMR: $\delta$ $6.51(1 \mathrm{H}, \mathrm{s}, \mathrm{H}-13), 6.47$ (1H, br d, J 6.4, H-14), 4.80 (1H, d, J 1.5, H-7a), 4.64 (1H, dt, $J$ 6.4, 2.6, $\mathrm{H}-10), 3.85\left(3 \mathrm{H}, \mathrm{s}, \mathrm{C} 11-\mathrm{OCH}_{3}\right), 3.83\left(3 \mathrm{H}, \mathrm{s}, \mathrm{C} 12-\mathrm{OCH}_{3}\right), 3.78-3.71(1 \mathrm{H}, \mathrm{m}), 3.41-3.33(1 \mathrm{H}, \mathrm{m})$, 2.97-2.87 $(2 \mathrm{H}, \mathrm{m}), 2.76-2.66(2 \mathrm{H}, \mathrm{m}), 2.65-2.55(1 \mathrm{H}, \mathrm{m}), 2.48-2.28\left(2 \mathrm{H}, \mathrm{AB}\right.$ q of d, $J_{\mathrm{g}} 13.0, J_{\mathrm{v}}$ 2.6, H-9), 2.23-2.00 (1H, m), 2.00-1.84 $(1 \mathrm{H}, \mathrm{m}), 1.49-1.35(1 \mathrm{H}, \mathrm{m}) .{ }^{13} \mathrm{C}$ NMR: $\delta 152.2,146.0$, $142.7,135.5,132.7,131.3,128.6,116.9,116.5,116.2,110.2,61.6,56.0,55.9,50.7,49.8,40.6$, 33.1, 32.6 (2C), 29.6, 27.6. IR $v_{\max }$ (thin film): 2248 (w, CN), 2208 (sharp, s, N-CN) cm ${ }^{-1}$.

\section{Reaction of the 3-Aza[6](1,7)naphthalenophane (1d) with 1,1-Dicyanoethylene}

To a stirred solution of the 3-aza[6](1,7)naphthalenophane (1d) (165 mg, $0.502 \mathrm{mmol})$ in dry benzene $(5 \mathrm{~mL})$ was added a solution of 1,1-dicyanoethylene $(47 \mathrm{mg}, 0.603 \mathrm{mmol})$ in dry benzene $(1 \mathrm{~mL})$. The solution was stirred under nitrogen at room temperature for $48 \mathrm{~h}$. The solvent was evaporated to dryness. The residue was dissolved in chloroform and subjected to p.t.l.c. (toluene $/ 2 \%$ isopropanol; 7 developments) to give three fractions. Fraction $1\left(R_{\mathrm{f}} 0.70\right)$ was identified as the starting material (1d) (70 $\mathrm{mg}, 0.213 \mathrm{mmol}, 42 \%)$.

Methyl 9,9-dicyano-1,3,4,5,6,7a,8,10-octahydro-11,12-dimethoxy-10,7-metheno-7Hnaphth[1,8-de]azecine-3-carboxylate $(\mathbf{4 b})$. Fraction $2\left(R_{\mathrm{f}} 0.65\right)$ yielded the adduct $\mathbf{4 b}(25 \mathrm{mg}$, $0.061 \mathrm{mmol}, 12 \%$ ) as colourless prisms from diethyl ether, m.p. 162-163 ${ }^{\circ} \mathrm{C}$. (Found: $\mathrm{C}, 67.8 ; \mathrm{H}$, 6.2; N, 10.3. $\mathrm{C}_{23} \mathrm{H}_{25} \mathrm{~N}_{3} \mathrm{O}_{4}$ requires $\left.\mathrm{C}, 67.8 ; \mathrm{H}, 6.2 ; \mathrm{N}, 10.3 \%\right)$. Mass spectrum: $m / z 407\left(\mathrm{M}^{+}, 2\right.$, accurate mass 407.1847. $\mathrm{C}_{23} \mathrm{H}_{25} \mathrm{~N}_{3} \mathrm{O}_{4}$ requires 407.1845), 329 (70), 314 (10), 227 (100), 102 (35). ${ }^{1} \mathrm{H}$ NMR: $\delta 6.51(1 \mathrm{H}, \mathrm{s}, \mathrm{H}-13), 6.18(1 \mathrm{H}, \mathrm{br} \mathrm{d}, J$ 5.9, H-14), $4.92(1 \mathrm{H}, \mathrm{d}, J$ 6.1, H-10), 4.20 $(1 \mathrm{H}, \mathrm{td}, J 2.6,1.5, \mathrm{H}-7 \mathrm{a}), 4.09-4.05(1 \mathrm{H}, \mathrm{m}), 3.97\left(3 \mathrm{H}, \mathrm{s}, \mathrm{C} 11-\mathrm{OCH}_{3}\right), 3.85\left(3 \mathrm{H}, \mathrm{s}, \mathrm{C} 12-\mathrm{OCH}_{3}\right)$, $3.70\left(3 \mathrm{H}, \mathrm{s}, \mathrm{COOCH}_{3}\right), 3.28-3.16(2 \mathrm{H}, \mathrm{m}), 2.75-2.15(6 \mathrm{H}, \mathrm{m}), 2.38-2.26\left(2 \mathrm{H}, \mathrm{AB}\right.$ q of d, $J_{\mathrm{g}} 12.9$, $\left.J_{\mathrm{v}} 2.6, \mathrm{H}-9\right), 1.38-1.26(1 \mathrm{H}, \mathrm{m}) .{ }^{13} \mathrm{C}$ NMR: $\delta 155.1,151.2,144.3,134.1,130.4,130.0,125.1$, 
117.2, 116.9, 111.6, 61.5, 55.9, 53.4, 52.6, 42.2, 40.9, 40.4, 33.1, 32.9, 30.0, 29.9 (not all peaks visible). IR $v_{\max }$ (thin film): 1698 (sharp, $\left.\mathrm{s}, \mathrm{C}=\mathrm{O}\right) \mathrm{cm}^{-1}$.

Methyl 8,8-dicyano-1,3,4,5,6,7a,9,10-octahydro-11,12-dimethoxy-10,7-metheno-7Hnaphth[1,8-de] azecine-3-carboxylate $(\mathbf{5 b})$. Fraction $3\left(R_{\mathrm{f}} 0.60\right)$ afforded the adduct $\mathbf{5 b}(20 \mathrm{mg}$, $0.049 \mathrm{mmol}, 10 \%$ ) as colourless prisms from diethyl ether, m.p. 156-157 ${ }^{\circ} \mathrm{C}$. (Found: $\mathrm{C}, 67.4 ; \mathrm{H}$, 6.2; N, 10.2. $\mathrm{C}_{23} \mathrm{H}_{25} \mathrm{~N}_{3} \mathrm{O}_{4}$ requires $\left.\mathrm{C}, 67.8 ; \mathrm{H}, 6.2 ; \mathrm{N}, 10.3 \%\right)$. Mass spectrum: $m / z 407\left(\mathrm{M}^{+}, 1\right.$, accurate mass 407.1840. $\mathrm{C}_{23} \mathrm{H}_{25} \mathrm{~N}_{3} \mathrm{O}_{4}$ requires 407.1843), 329 (60), 314 (10), 227 (100), 102 (32). ${ }^{1} \mathrm{H}$ NMR: $\delta 6.51(1 \mathrm{H}, \mathrm{s}, \mathrm{H}-13), 6.41(1 \mathrm{H}, \mathrm{br} \mathrm{d}, J 6.2, \mathrm{H}-14), 4.69$ (1H, d, $\left.J 1.5, \mathrm{H}-7 \mathrm{a}\right), 4.46$ $(1 \mathrm{H}, \mathrm{dt}, J 6.3,2.6, \mathrm{H}-10), 4.09-4.05(1 \mathrm{H}, \mathrm{m}), 3.85\left(3 \mathrm{H}, \mathrm{s}, \mathrm{C} 11-\mathrm{OCH}_{3}\right), 3.82\left(3 \mathrm{H}, \mathrm{s}, \mathrm{C} 12-\mathrm{OCH}_{3}\right)$, $3.72\left(3 \mathrm{H}, \mathrm{s}, \mathrm{COOCH}_{3}\right), 3.28-3.16(2 \mathrm{H}, \mathrm{m}), 2.75-2.15(6 \mathrm{H}, \mathrm{m}), 2.47-2.32\left(2 \mathrm{H}, \mathrm{AB}\right.$ q of d, $J_{\mathrm{g}} 12.8$, $\left.J_{\mathrm{v}} 2.6, \mathrm{H}-9\right), 1.39-1.25(1 \mathrm{H}, \mathrm{m}) .{ }^{13} \mathrm{C}$ NMR (from mixture $\left.4 \mathbf{b} ; \mathbf{5 b}\right): \delta 158.4,151.9,147.4,142.2$, $135.1,133.0,131.5,130.3,128.6,116.8,116.3,110.4,61.5,55.8,53.5,52.5,49.8,49.5,41.1$, 33.0, 32.5, 30.5, 29.8. IR $v_{\max }$ (thin film): 1700 (sharp, $\left.\mathrm{s}, \mathrm{C}=\mathrm{O}\right) \mathrm{cm}^{-1}$.

\section{Reaction of the 3-Aza[6](1,7)naphthalenophane (1b) with 1,1-Diethyl Methylenemalonate}

To a stirred solution of the 3-aza[6](1,7)naphthalenophane (1b) (153 $\mathrm{mg}, 0.517 \mathrm{mmol})$ in dry benzene $(5 \mathrm{~mL})$ was added a solution of 1,1-diethyl methylenemalonate ( $89 \mathrm{mg}, 0.517 \mathrm{mmol})$. The solution was refluxed under nitrogen for $46 \mathrm{~h}$. The solvent was evaporated to dryness. The residue was dissolved in dichloromethane and subjected to p.t.l.c. (toluene/2\% isopropanol; 7 developments) to afford two fractions.

Diethyl 3-cyano-1,3,4,5,6,7a,8,10-octahydro-11,12-dimethoxy-10,7-metheno-7H-naphth[1,8de]azecine-9,9(2H)-dicarboxylate $(4 \mathrm{c})$. Fraction $1\left(R_{\mathrm{f}} 0.45\right)$ yielded the adduct $4 \mathrm{c}(110 \mathrm{mg}$, $0.235 \mathrm{mmol}, 45 \%)$ as colourless prisms from diethyl ether/light petroleum, m.p. $132-133{ }^{\circ} \mathrm{C}$. (Found: C, 66.5; H, 6.9; N, 5.9. $\mathrm{C}_{26} \mathrm{H}_{32} \mathrm{~N}_{2} \mathrm{O}_{6}$ requires $\mathrm{C}, 66.6 ; \mathrm{H}, 6.9 ; \mathrm{N}, 6.0 \%$ ). Mass spectrum: $m / z 468\left(\mathrm{M}^{+}, 3.5\right.$, accurate mass 468.2263. $\mathrm{C}_{26} \mathrm{H}_{32} \mathrm{~N}_{2} \mathrm{O}_{6}$ requires 468.2258), 296 (85), 295 (20), 227 (100), 214 (35), 127 (60), 99 (45). ${ }^{1} \mathrm{H}$ NMR: $\delta 6.38$ (1H, s, H-13), 6.22 (1H, br d, J 6.0, H14), 4.88 (1H, d, J 6.0, H-10), 4.13-4.10 (1H, m, H-7a), 4.27-3.93 (5H, m), 3.81 (3H, s, C11$\left.\mathrm{OCH}_{3}\right), 3.79\left(3 \mathrm{H}, \mathrm{s}, \mathrm{C} 12-\mathrm{OCH}_{3}\right), 3.73-3.67(1 \mathrm{H}, \mathrm{m}), 3.37-3.26(1 \mathrm{H}, \mathrm{m}), 2.96-2.83(2 \mathrm{H}, \mathrm{m}), 2.63-$ $2.45(2 \mathrm{H}, \mathrm{m}), 2.43,2.11\left(2 \mathrm{H}, \mathrm{AB}\right.$ q of d, $\left.J_{\mathrm{g}} 13.0, J_{\mathrm{v}} 2.6, \mathrm{H}-8\right), 2.09-1.91(1 \mathrm{H}, \mathrm{m}), 1.89-1.78(1 \mathrm{H}$, $\mathrm{m}), 1.42-1.24(1 \mathrm{H}, \mathrm{m}), 1.26\left(3 \mathrm{H}, \mathrm{t}, J 7.2, \mathrm{CH}_{3}\right), 1.17\left(3 \mathrm{H}, \mathrm{t}, J 7.2, \mathrm{CH}_{3}\right) .{ }^{13} \mathrm{C} \mathrm{NMR}: \delta 171.6$, $170.4,151.1,150.5,143.9,137.0,133.9,129.3,128.0,117.8,109.6,61.7,61.5,61.2,59.6,56.0$, $55.8,49.2,43.4,40.2,35.2,33.0,28.6,27.8,14.1,13.9$. IR $v_{\max }$ (thin film): 2208 (sharp, s, CN), $1730($ broad, $\mathrm{s}, \mathrm{C}=\mathrm{O}) \mathrm{cm}^{-1}$.

Diethyl 3-cyano-1,3,4,5,6,7a,9,10-octahydro-11,12-dimethoxy-10,7-metheno-7H-naphth[1,8de]azecine-8,8(2H)-dicarboxylate $(\mathbf{5 c})$. Fraction $2\left(R_{\mathrm{f}} 0.40\right)$ afforded the adduct $5 \mathrm{c}(120 \mathrm{mg}$, $0.256 \mathrm{mmol}, 50 \%$ ) as colourless prisms from diethyl ether/light petroleum, m.p. $129-130{ }^{\circ} \mathrm{C}$. (Found: C, 67.0; H, 6.9; N, 5.9. $\mathrm{C}_{26} \mathrm{H}_{32} \mathrm{~N}_{2} \mathrm{O}_{6}$ requires $\mathrm{C}, 66.6 ; \mathrm{H}, 6.9 ; \mathrm{N}, 6.0 \%$ ). Mass spectrum: $m / z 468\left(\mathrm{M}^{+}, 15\right.$, accurate mass 468.2263. $\mathrm{C}_{26} \mathrm{H}_{32} \mathrm{~N}_{2} \mathrm{O}_{6}$ requires 468.2258), 296 (85), 295 (20), 227 (100), 214 (35). ${ }^{1} \mathrm{H}$ NMR: $\delta 6.34$ (1H, s, H-13), 6.25 (1H, br d, J 6.2, H-14), 4.76 (1H, d, $J$ 1.5, H-7a), 4.29 (1H, dt, J 6.2, 2.7, H-10), 4.26-4.18 (2H, m), $4.02(2 \mathrm{H}, \mathrm{qd}, J 7.1,1.3), 3.80$ (3H, s, $\left.\mathrm{C} 11-\mathrm{OCH}_{3}\right), 3.80\left(3 \mathrm{H}, \mathrm{s}, \mathrm{C} 12-\mathrm{OCH}_{3}\right), 3.71(1 \mathrm{H}, \mathrm{dt}, J 14.3,3.3), 3.67-3.45(1 \mathrm{H}, \mathrm{m}), 3.55-3.45$ 
(1H, m), 2.93-2.80 (1H, m), 2.59-2.51 (3H, m), 2.32 (2H, d, J 2.7, H-9), 2.08-1.96 (1H, m), 1.64$1.74(1 \mathrm{H}, \mathrm{m}), 1.30\left(3 \mathrm{H}, \mathrm{t}, J 7.1, \mathrm{CH}_{3}\right), 1.32-1.18(1 \mathrm{H}, \mathrm{m}), 1.14\left(3 \mathrm{H}, \mathrm{t}, J 7.1, \mathrm{CH}_{3}\right) .{ }^{13} \mathrm{C} \mathrm{NMR}: \delta$ $171.1,170.6,150.8,147.7,142.5,138.5,133.1,132.2,130.3,117.7,108.7,61.7,61.6,61.5,59.8$, $56.1,55.7,49.4,48.4,35.2,34.0,32.8,29.3,28.2,14.1,14.0 . \mathrm{IR} v_{\max }$ (thin film): 2208 (sharp, s, $\mathrm{CN}), 1730$ (broad, $\mathrm{s}, \mathrm{C}=\mathrm{O}) \mathrm{cm}^{-1}$.

\section{Acknowledgements}

The award of an E. T. Taylor Postgraduate Award (to W.J.) is gratefully acknowledged, together with a grant in support of this work through the Australian Research Council. We also thank the University of Tasmania and the University of Wollongong for support.

\section{References and Footnotes}

1. Kiselev, V. D.; Kashaeva, E. A.; Potapova, L. N.; Iskhakova, G. G. Russ. Chem. Bull., Int. Ed. 2004, 53, 51.

2. Jones, W. H.; Mangold, D.; Pleininger, D. H. Tetrahedron 1962, 18, 267.

3. Wiberg, K. B.; O' Donnell, M. J. J. Am. Chem. Soc. 1979, 101, 6660.

4. Klarner, F.-G.; Breitkopf, V. Eur. J. Org. Chem. 1999, 2757.

5. He, Y.; Junk, C.P.; Lemal, D.M. Org. Lett. 2003, 5, 2135.

6. In some cases, however, [2+2] cycloaddition may occur, for example with [6](1,4)naphthalenophane and tetracyanoethylene. See Tobe, Y.; Takemura, A.; Jimbo, M.; Takahashi, T.; Kobiro, K.; Kakiuchi, K. J. Am. Chem. Soc. 1992, 114, 3479.

7. Bremner, J. B.; Engelhardt, L. M.; White, A. H.; Winzenberg, K. N. J. Am. Chem. Soc. 1985, 107, 3910.

8. Bremner, J. B.; Winzenberg, K. N. Aust. J. Chem. 1986, 39, 1.

9. Yao, J. X.; Bremner, J. B.; Skelton, B. W.; White, A. H.; Winzenberg, K. N. Aust. J. Chem. 1989, 42, 321.

10. Bremner, J. B.; Thirasasana, N. Aust. J. Chem. 1982, 35, 2307.

11. Solo, A. J.; Sachdev, H.; Gilani, S. S. H. J. Org. Chem. 1965, $30,769$.

12. Kaftory, M. Acta Crystallogr., Ser: B, 1980 B36, 597.

13. Kaftory, M. Acta Crystallogr., Ser: B, 1981 B37, 268.

14. Agmon, I.; Kaftory, M.; Ashkenazi, P.; Muller, R.; von Philipsborn, W.; Ginsburg, D., Heterocycles, 1989 28, 33. 